Marquette University

e-Publications@Marquette

$1-1-2007$

\title{
An Ethical Basis for Relationship Marketing: A Virtue Ethics Perspective
}

Patrick Murphy

University of Notre Dame

Gene R. Laczniak

Marquette University, eugene.laczniak@marquette.edu

Graham Wood

University of Salford

Accepted version. European Journal of Marketing, Vol. 41, No. 1/2 (2007): 37-57. DOI. (C) 2007

Emerald. Used with permission. 


\title{
An Ethical Basis for Relationship Marketing: A Virtue Ethics Perspective
}

\author{
Patrick E. Murphy \\ Mendoza College of Business, University of Notre Dame \\ Notre Dame, IN \\ Gene R. Laczniak \\ Marquette University \\ Milwaukee, WI \\ Graham Wood \\ School of Management, University of Salford \\ Salford, UK
}

\begin{abstract}
:
Purpose-The purpose of this paper is to provide an ethical foundation for relationship marketing using a virtue ethics approach.

Design/methodology/approach-The approach is a conceptual one providing a background on relationship marketing from both American and European perspectives. Earlier studies published in EJM on relationship marketing are featured in a table.

Findings-The proposed ethical relationship marketing approach has three stages (establishing, sustaining and reinforcing) that are paired with specific virtues (trust, commitment and diligence). These and other facilitating virtues are shown in a figure.

Research limitations/implications-The model and its components have yet to be tested empirically. Some strategies for undertaking such research are discussed.

Practical implications-Several European and American companies that currently practice ethical relationship marketing are discussed.

Originality/value-Although relationship marketing has been studied for a

European Journal of Marketing, Vol 41, No. 2 (2007): pg. 37-57. DOI. This article is @ Emerald and permission has been granted for this version to appear in e-Publications@Marquette. Emerald does not grant permission for this article to be further copied/distributed or hosted elsewhere without the express permission from Emerald.
\end{abstract}


NOT THE PUBLISHED VERSION; this is the author's final, peer-reviewed manuscript. The published version may be accessed by following the link in the citation at the bottom of the page.

number of years by many scholars, the ethical basis of it has not been thoroughly examined in any previous work.

From the management consulting literature:

Unless you build relationships of trust with your customers, listen, learn, and respond to their changing needs, and empower your people to correct mistakes when they occur (not days or weeks after they have been measured), you will not establish an environment for long-lasting customer relationships (Pollard, 1996, pp. 74-75).

From the boardroom: Mark Walsh, the CEO of VerticalNet, a provider of e-business infrastructures writes:

A technology vendor is crazy if he or she feels that these firms will overthrow these personal relationships simply by putting new technologies in place. These technologies may make existing relationships more efficient, but they will not transform them (Walsh quoted in Cohen and Prusak, 2001, p. 54).

From the lessons of history: an American visitor to Oxford marveled at the smooth green perfection of the lawn inside the quadrangle of one of Oxford University's venerable colleges. While he stood admiring it, a groundskeeper appeared through one of the entries. The visitor asked him the secret of that lawn, so superior to any he had seen in the Us. The groundskeeper said:

There's no secret. Only soil, seed, water, and 500 years of rolling.

It does not take anything like 500 years to build social capital in an organization, but it does take consistent effort over time. There is no quick fix (Cohen and Prusak, 2001, p. 185).

These three excerpts aptly capture the essence of relationship marketing (RM) from a virtue ethics perspective. The first two quotes are by former executives who believe that trust and earned reputation are keys to establishing relationships in service and dot com businesses. The third quote indicates that it takes time, and serious cultivation (i.e. commitment and diligence), to build and maintain a truly lasting relationship.

This paper focuses on the ethical basis of relationship marketing by taking a virtue ethics perspective. We envision relationship marketing as passing through three stages -establishment,

European Journal of Marketing, Vol 41, No. 2 (2007): pg. 37-57. DOI. This article is @ Emerald and permission has been granted for this version to appear in e-Publications@Marquette. Emerald does not grant permission for this article to be further copied/distributed or hosted elsewhere without the express permission from Emerald. 
maintenance and reinforcement. Each stage is associated with a dominant ethical virtue and the entire process is embedded in several other overarching virtues. It is our contention that RM is inherently an ethical activity, since enduring relationships cannot be built or sustained without a solid moral foundation.

Before moving on, it is important to define and clarify our view of relationship marketing. As Kotler and Keller (2006), Gummesson (1999) and others have stated, RM has the aim of building mutually satisfying long-term relations with key parties-customers, suppliers, distributors-in order to earn and retain their businesses. Norberg (2001) listed 14 definitions of RM taken from the literature during the last 15 years. Most of the definitions indicate that there are separate phases of a relationship such as its foundation and maintenance. Furthermore, elements like trust, equity and involvement tend to foster this bond and contribute to long-term partner satisfaction.

This paper is divided into four parts. First, we examine the historical roots of relationship marketing. The second section characterizes both the American and European views on RM. Third, we present a model of ethical relationship marketing and discuss its components. Within the model, the theory of virtue and several relevant virtues that we believe are essential for successful RM are examined. In the subsequent discussion, we lay the groundwork for those who might attempt to measure the presence of these characteristics in business and consumer partnerships that have been claimed to be successful. Finally, we draw implications for marketing managers and researchers.

\section{Historical roots of relationship marketing}

Relationship marketing usually results in strong economic, technical and social ties among the stakeholder parties thereby reducing their transaction costs and increasing exchange efficiencies. Included in RM are not only buyer/seller exchanges but also business partnerships, strategic alliances, and cooperative marketing networks. Several aspects of the relationship marketing "concept" are unique. First, the relationship typically involves seller-customer exchange but it could involve any stakeholder relationship (Morgan and Hunt, 1994), i.e. it applies to supplier-seller exchange, manufacturer-distributor exchange, etc. Second, the emphasis of the exchange is not only on

European Journal of Marketing, Vol 41, No. 2 (2007): pg. 37-57. DOI. This article is @ Emerald and permission has been granted for this version to appear in e-Publications@Marquette. Emerald does not grant permission for this article to be further copied/distributed or hosted elsewhere without the express permission from Emerald. 
healthy economic relationships but also on emotional ties that extend into the long-term. In relationship marketing, "the value of future deliveries will always be greater than the value of any existing transaction" (Davis and Mandrodt, 1996). Thus, the case can be made that due to its inclusiveness and long-term orientation, the RM paradigm is a unique construct for analyzing the marketing process.

Certainly, it must be recognized that the crafting and nurturing of such relationships has been discussed in the marketing literature in Europe and the US for some time. When relationship marketing involves customers, it closely resembles the effective application of the marketing concept (Varva, 1992). Marketing historian Stanley Hollander and his colleagues (Keep et al., 1996) opine that academic interest in marketing and managing various channel relationships is a well-worn concern. They also report that Alderson's (1957) "systems" approach to marketing and Fisk's (1967) "consensus command systems" address relationship management. Similarly, the classic work of the late management guru Peter Drucker (1979)-"the business of business is getting and keeping customers"-establishes the longstanding managerial concern of overseeing relationships. Drucker (1973) also applies this thinking to the effective linkage of suppliers, subcontractors, and partners (e.g. the Japanese, for over a century, have been masters at creating relationships among independent networks).

The historical perspective of RM in Europe is tied closely with network analysis and the Industrial Marketing and Purchasing (IMP) group that began in the 1980s. One European observer remarked:

Basic IMP-related research on interaction, relationships and networks on industrial markets (the network approach) predates the contemporary research interest in RM by a decade or two (Mattson, 1997).

The network and relationship marketing topics are explored extensively in a volume that contains 26 papers written by leading European scholars (Gemünden et al., 1997).

The upshot of the above commentary is that RM is not so much a new concept but rather a more relevant one in today's business environment with increased global competition and technological development leading to more effective and efficient business

European Journal of Marketing, Vol 41, No. 2 (2007): pg. 37-57. DOI. This article is @ Emerald and permission has been granted for this version to appear in e-Publications@Marquette. Emerald does not grant permission for this article to be further copied/distributed or hosted elsewhere without the express permission from Emerald. 
communication (Anton, 1996). While the elements of relationship marketing are historically rooted in past behavior and theoretical analysis, this paper contends that its practice today can be better executed if one recognizes the connection of relationship marketing to another theoretical framework with even deeper historical roots-virtue ethics (MacIntyre, 1984; Solomon, 1992). Consistent with the arguments advanced by Hosmer (1994), who sees the virtues of trust, commitment, and effort as instrumental to stakeholder management, we view such virtues as providing the theoretical and moral underpinnings for the successful practice of RM.

\section{American perspective on relationship marketing}

Relationship marketing as a term first appeared in the US marketing literature in a 1983 paper by Berry (1995). Services marketing provided the context for introducing RM. The general notion (explored above) has been discussed by many marketing writers using different descriptors for a long time. However, as an identifiable subject within the overall domain of marketing in the US, RM is a relatively recent phenomenon. What makes RM so pervasive is that it has been shown to be applicable to all sectors of marketing-consumer goods, services and business-to-business settings.

Many academic studies on relationship marketing have been conducted in the last 20 years. Several books with RM in the title have appeared in Europe (Buttle, 2004; Christopher et al., 1991; Hougaard et al., 2004) and North America (Barnes, 2001; Gordon, 1998; McKenna, 1991). Research on RM has mushroomed. The greatest stimuli to the growing literature probably were the conferences held on the topic at Emory University that produced 57 papers in the first volume (Sheth and Parvatiyar, 1994) and 54 in the second (Parvatiyar and Sheth, 1996). A second significant development was the publication of a special issue of Journal of the Academy of Marketing Science on RM in Fall 1995. Because of this substantial body of scholarly work, RM is now recognized as a significant paradigm shift within the marketing field.

The "values" that underpin RM began to be analyzed in the late 1990s. This research shows that confidence/trust is a primary reason customers maintain relationships (Gwinner et al., 1998), loyalty is a key element in relationships (Oliver, 1999; Sirdeshmukh et al., 2002)

European Journal of Marketing, Vol 41, No. 2 (2007): pg. 37-57. DOI. This article is (C) Emerald and permission has been granted for this version to appear in e-Publications@Marquette. Emerald does not grant permission for this article to be further copied/distributed or hosted elsewhere without the express permission from Emerald. 
and satisfaction, trust and commitment play differing roles in customer relationships (Garbarino and Johnson, 1999). Fournier et al. (1998) called for more analysis of the value foundations of RM. Several articles have examined the notions of values and ethics in RM: the ethical and legal foundations of relational exchange (Gundlach and Murphy, 1993); relational norms can lead to both positive economic self interest as well as commitment and satisfaction outcomes (Joshi, 1994); trustworthiness (promise keeping) and justice are keys to understanding RM (Soellner, 1996); and "commitment" is central to RM (Gruen et al., 2000). But writings connecting all these values or qualities are absent from the literature.

\section{European perspective on relationship marketing}

RM also has a longstanding tradition within the European academic marketing field. Baker (1994) observed that just as relationship marketing was beginning to preoccupy theorists in the US, work had been in progress for over twenty years in Europe. This statement was not meant as a boast, but to indicate that the antecedents of relationship marketing can be traced back to the $1950 \mathrm{~s}$ and 1960s in the work of the "Copenhagen School" (Grönroos, 1994). Before the marketing mix (or four-Ps) paradigm became dominant, Europeans were arguing for a wider view of marketing. Grönroos (1994) asserts that the eventual hegemony of the four-Ps paradigm could be "characterized as a step back to the level of, in a sense equally simplistic, microeconomics theory of the 1930s" (p. 351). In other papers, Grönroos (1989, 1991, 1994) has linked the subsequent development of marketing theory in Europe to its basis in the interaction/network approach and to industrial marketing perspectives. These insights led Gummesson (1987) to coin the term "part-time marketers" for those non-marketing personnel involved in these transactions. Marketing was no longer the preserve of specialists, but involved a wider group from other functions or departments. "Buyers" could now come from a number of areas rather than only the purchasing function (Nooteboom, 1992).

As already noted, this revised perspective was disseminated throughout Europe partly through the IMP Group (Ford, 1990; Hakansson, 1982). The work demonstrated that especially within industrial marketing these interactions lead to the development of social relationships and relationship building. This contrasts with the

European Journal of Marketing, Vol 41, No. 2 (2007): pg. 37-57. DOI. This article is @ Emerald and permission has been granted for this version to appear in e-Publications@Marquette. Emerald does not grant permission for this article to be further copied/distributed or hosted elsewhere without the express permission from Emerald. 
classic American four-Ps paradigm where the seller is active but the buyer is passive and no personalized relationships are supposed to exist, at least initially.

This change in theoretical perspective mirrored an evolution in marketing practice. Consumer marketing began to emphasize customer retention and loyalty rather than customer acquisition, while in industrial marketing a fundamental shift occurred in the make/buy decision with the result that outsourcing grew rapidly. Both these trends led to a desire to build more stable and lasting relationships. Key concepts evolved such as reciprocity, ensuring both parties benefit from the relationship, and the need for a sense of social solidarityequitable partnership for all (Nooteboom, 1992).

Engaging in co-operative relationships inevitably increases the vulnerability of the parties and leads directly to the central argument of this paper, that relationship marketing also must be ethical marketing. Where relationships are marked by reciprocity or solidarity, there is concern for reputation, trustworthiness and mutual advantage (Gherardi and Masiero, 1990; Juttner and Wehrli, 1994). Table I lists twenty-three articles published in EJM over the last ten years that focus on RM. A number of observations have been made about RM both in Europe and throughout the world. They are shown in the summary column. Trust was the dominant ethical concept described in these articles but commitment also is examined in several of them.

Only one article in the European literature focuses on an ethical approach in examining RM (Kavaili et al., 1999). This research concludes that RM is strategic but also has ethical dimensions. It is on this aspect that our analysis builds. We take a specific ethical theoryvirtue ethics-and show how it is consonant with effective relationship marketing.

\section{A model of ethical relationship marketing}

Figure 1 depicts our model of ethical RM. Beyond establishment and maintenance, it adds a third stage to the relationship processreinforcement[1]. While many ethical underpinnings are essential during the RM process, we envision the virtues of trust, commitment and diligence as key to establishing, sustaining and reinforcing relationships. Before discussing the details that are essential to making RM both commercially and morally viable, we review briefly several

European Journal of Marketing, Vol 41, No. 2 (2007): pg. 37-57. DOI. This article is @ Emerald and permission has been granted for this version to appear in e-Publications@Marquette. Emerald does not grant permission for this article to be further copied/distributed or hosted elsewhere without the express permission from Emerald. 
factors examined in earlier research and discuss how virtue ethics is unique from other ethical theories.

We envision trust as the bridge between the objectives of improved ethical behavior in marketing and the desire to see marketing develop in a new direction through relationship marketing. For trust to perform its role as a bridge, it must be characterized as a virtue (Solomon and Flores, 2001) and relationships marked by trust must be constitutive of the virtues. How might this look?

\section{Virtue ethics in relationship marketing}

Though various ethical theories have been applied to marketing situations, they come up short in explaining the full substantive basis of RM. To be sure, on-going marketing relationships depend on mutual economic benefit between the partners but then relationships usually go beyond the cost-benefit calculations associated with consequencesoriented approaches. Nantel and Weeks (1996), writing previously in $E J M$, indicated that although marketing primarily draws from the utilitarian approach to ethics, additional deontological, especially duty based, thinking should be used[2]. However, they find even the best intentions and sense of honour amongst partners in RM are sometimes not enough to make a relationship endure over long periods of time.

We believe a set of "good habits," commonly called virtues, are essential for the individuals and organizations involved in RM. Virtue ethics is different from the other theories in that it focuses on the individual and the organization rather than a problem or dilemma. In addition to practicing good habits and placing emphasis on individual/corporate character, other features of virtue ethics include the importance of imitating ethical behavior of mentors/elders, that virtues are learned and practiced and that the aspirations of the community are a big motivator. Still another aspect of the virtue approach is the "ethic of the mean" which states that practitioners of virtue ethics succeed by seeking balance in their lives (for more complete discussion of virtue ethics in marketing, see Murphy, 1999; Murphy et al., 2005; Williams and Murphy, 1992).

\section{Virtues inherent in ethical RM}

A number of other virtues associated with relationship marketing have been identified in the literature: honesty (Buttle,

European Journal of Marketing, Vol 41, No. 2 (2007): pg. 37-57. DOI. This article is @ Emerald and permission has been granted for this version to appear in e-Publications@Marquette. Emerald does not grant permission for this article to be further copied/distributed or hosted elsewhere without the express permission from Emerald. 
1996; Swan et al., 1985); fairness (Buttle, 1996; Gundlach and Murphy, 1993); benevolence (Buttle, 1996; Ganesan, 1994); integrity (Moorman et al., 1993; Morgan and Hunt, 1994); reliability (Morgan and Hunt, 1994; Swan et al., 1985); reputation (Ganesan, 1994; Nooteboom, 1992); commitment (Buttle, 1996; Dwyer et al., 1987; Ganesan, 1994; Garbarino and Johnson, 1999; Gruen et al., 2000; Gundlach and Murphy, 1993; Morgan and Hunt, 1994), and of course trust (Anderson and Narus, 1990; Buttle, 1996; Ganesan, 1994; Moorman et al., 1993; Morgan and Hunt, 1994; Nooteboom, 1992; Selnes, 1998; Swan et al., 1985). Organizations are seeking honest, fair, reliable, benevolent partners who will commit themselves to the relationship and prove trustworthy. In other words, they seek ethical partners.

Although this impressive list of virtues has been associated with RM, our view is that several of these are building blocks to any longterm partnership. Specifically, for it to operate as intended, RM appears to be a multi-stage process drawing on three essential virtues. In this manner, the confluence of trust, commitment and diligence becomes the glue to connect the virtue ethics perspective for successful relationship marketing. These three were identified by Hosmer (1994) as outcomes in effective stakeholder management (for discussions of stakeholder thinking in marketing, see EJM, Vol. 39 No. $9 / 10,2005)$. However, he did not propose the sequential nature that we see as critical for RM. They are as follows:

Trust $\rightarrow$ Commitment $\rightarrow$ Diligence

Organizations involved in RM increase their vulnerability to opportunistic behavior when depending on their partners. Without trust, partners will reduce their vulnerability and step back from the relationship. Trust is at the core of ethical relationship marketing and once it is established, the partners can then exhibit commitment to the relationship.

As noted earlier, commitment has been identified by several writers as an essential component of RM. The final virtue associated with RM is diligence. Hosmer described this trait in a more pedestrian manner: effort. We see it as not only encompassing effort but also as casting a watchful eye toward sustaining the relationship over time.

European Journal of Marketing, Vol 41, No. 2 (2007): pg. 37-57. DOI. This article is @ Emerald and permission has been granted for this version to appear in e-Publications@Marquette. Emerald does not grant permission for this article to be further copied/distributed or hosted elsewhere without the express permission from Emerald. 
After trust is examined, we then discuss the other two virtues essential for ethical RM.

\section{The critical role of trust}

Trust is widely regarded as being an essential element for exchanges moving from a transaction-base to a relationship-base. This notion is nearly universally shared by writers in marketing and other fields (for book length treatments of trust, see Fukuyama, 1995; Gambetta, 1988; Solomon and Flores, 2001). In summarizing much of the work undertaken on trust in the organizational theory literature, Hosmer (1995) drew several conclusions: trust "occurs under conditions of vulnerability and dependence upon the behavior of others"; "is associated with willing, not forced, cooperation"; and "is accompanied by an accepted duty to protect the rights and interests of others" (pp. 391-392). This approach builds upon "social exchange theory" introduced by Homans (1974), who saw cooperation as essential in group relationships[3].

\section{Trust defined}

Over time, many definitions of trust have been proposed (for a summary, see Mittal, 1996; Wilson, 1995). The definition most marketing writers embrace is Rotter's (1967): trust is a generalized expectancy held by an individual that the word of another can be relied upon. Using this definition, trust implies a certain expectation and confidence about the behavior of others and an implicit vulnerability to that person's actions. Because trust is cooperative and not enforceable, it is an inherently ethical notion.

One of the driving forces for trust in relationship marketing is the "self-heightening cycle," i.e. trusting behavior begets trusting behavior. Managers who begin a relationship often expand the scope of their trust over time. This mutual trust leads to a number of positive outcomes-greater communication and feedback, better problem solving, effective delegation and acceptance of common goals and sharing of responsibility (Gundlach and Murphy, 1993; Zineldin, 1998).

\section{Trust in marketing}

Trust as a variable influencing marketing managers and their behavior has received substantial analysis. The most extensive

European Journal of Marketing, Vol 41, No. 2 (2007): pg. 37-57. DOI. This article is (C) Emerald and permission has been granted for this version to appear in e-Publications@Marquette. Emerald does not grant permission for this article to be further copied/distributed or hosted elsewhere without the express permission from Emerald. 
examination has occurred in the industrial/business-to-business (B2B) settings (Anderson and Narus, 1990; Anderson and Weitz, 1989; Ganesan, 1994; Morgan and Hunt, 1994; Salmond, 1994). Trust has also been studied in retail relationships (Crosby et al., 1990; Dwyer et al., 1987; Ganesan, 1994) and within marketing channel relationships in Australia (Young and Wilkinson, 1989). Moorman et al. (1992, 1993) identified trust as a critical variable in marketing research relationships. Several studies also indicate that relational selling flourishes where high levels of trust are present (Hawes, 1994; Hawes et al., 1989).

Relationship marketing rests on the premise that customers and sellers are long term partners in an exchange process based on trust and rooted in the marketing concept. Both trust and the ethical execution of the classic marketing concept are driven by precisely the same characteristics. According to Shaw's (1997, pp. 39-40), Trust in the Balance, the creation of a marketplace requires three elements:

- Consumers perceive that product and service claims are honest and can be relied on.

- Integrity and consistency motives marketplace practices

- The well-being of consumers is kept in fair balance with the sometimes competing interests of the selling organization,

It would be useful to redefine trust as something to be created between parties. Thus, authentic trust, to use Solomon and Flores' (2001) term, is fundamentally a property of relationships. When we conceive of trust in this way, as built within relationships of reciprocity, mutual benefits and obligation, its value as a bridge between relationship marketing and ethics becomes clearer. This type of trust is manifested as a virtue. As Nooteboom (1992) noted, the partners move from a technology of selling to a process of interaction in which the relationship is pre-eminent.

Two tasks still remain to be completed before the link between relationship marketing and ethics can be cemented through trust: first, to examine what is meant by authentic trust and second, to describe what we will characterize as ethical relationship marketing.

Authentic trust is to be distinguished from blind, simple or naïve trust in that it is given and reciprocated only after being carefully

European Journal of Marketing, Vol 41, No. 2 (2007): pg. 37-57. DOI. This article is @ Emerald and permission has been granted for this version to appear in e-Publications@Marquette. Emerald does not grant permission for this article to be further copied/distributed or hosted elsewhere without the express permission from Emerald. 
considered. It results from dialogue, what Solomon and Flores (2001) describe as "conversations about trust". Such trust is "ultimately about relationships, and what it takes to create, maintain and restore them" (p. 32) and the lifeblood of RM is based upon a relationship with customers not their manipulation. Solomon and Flores (2001) could have been writing about relationship marketing when they observed that being customer-oriented is nonsense if the customer remains the "object" or the "target" of marketing.

It has already been argued (Wood et al., 2002) that too often relationship marketing is something done to customers rather than with them, and this is why we are arguing that the relationship element of relationship marketing has to be enduring and ethical. One recent development is the question of trust in online relationships (Sultan and Mooraj, 2001). Urban (2005a, b) proposed building trust as part of becoming a customer advocate:

Advocacy depends on trust, and marketers must learn about the determinants of trust and the dynamics of building enduring trust (Urban, 2005a, p. 158).

Much more analysis is needed in developing enduring ethical relationships. Few writers, researchers, and managers approach the notion of a relationship from the customer's point-of-view.

\section{Commitment and diligence in relationship marketing}

Ethical relationships require commitment. Morgan and Hunt (1994) argued for the importance of the link between commitment and trust. Similarly, Solomon and Flores (2001) indicated that trust is necessary for making commitments (p. 36). It has been postulated among relationship-connected stakeholders that the establishment of trust leads to commitment. But what precisely is the nature of this commitment? Gundlach and Murphy (1993) write that the characteristics of commitment are thought to be "stability, sacrifice, and loyalty." Morgan and Hunt (1994) define relationship commitment as "an exchange partner believing that an ongoing relationship with another is so important as to warrant maximum efforts at maintaining it; that is, the committed party believes that the relationship is worth working on to insure that is endures indefinitely." In other words; there seems to be a time and loyalty orientation to commitment that

European Journal of Marketing, Vol 41, No. 2 (2007): pg. 37-57. DOI. This article is @ Emerald and permission has been granted for this version to appear in e-Publications@Marquette. Emerald does not grant permission for this article to be further copied/distributed or hosted elsewhere without the express permission from Emerald. 
may not be evident in the virtue of trust. While an analogy to personal relationships may not be perfectly apropos, the connection between trust and commitment may be akin to that of engagement and marriage. That is, the establishment of trust allows for engagement of partners to occur, but commitment is what provides the impetus for the longer-term orientation represented in wedding vows.

The marketing literature contains a number of references to trust and commitment in RM. Morgan and Hunt (1994)-trust leads to relationship commitment; Soellner (1994)-trust stimulates the communication that makes commitments possible; and Day (1995)commitment often involves managerial actions leading to information sharing among partners that is totally open thus giving the cooperative arrangements a formal status not embodied in the initial cooperating teams but rather in the organizations themselves. Gundlach et al. (1995) stipulate that commitment has three components: an instrumental one dealing with some form of investment; an attitudinal one that can be described as psychological attachment, and a temporal one indicating the relationship occurs over time. White and Schneider (2000) liken levels of commitment to a ladder and found that "to achieve higher levels of commitment, a focus on assurance/responsiveness and empathy is required."

Commitment in RM also implies both making and keeping of promises (Bitner, 1995; Gronroos, 1991, 1994). Building a relationship involves promises, which are then fulfilled. To further promote the relationship, subsequent promises must be made and kept. Promise keeping is about commitment, even when it might be advantageous not to do so.

When relationships are established, disagreements and conflict are inevitable; but when ethical relationship marketing has been adopted, trust and commitment are a given. This leads to what Dwyer et al. (1987) call "the functional benefit of conflicts" (p. 24). That is, evolving relationships develop mechanisms assisting the resolution of conflicts by: improved communication, instituting grievance procedures, seeking equitable distribution of resources and power, and by adopting standardized approaches. As the partners learn to handle conflicts positively and to mutual satisfaction, the relationship is deepened because trust grows and the partners become more committed to one another. The presence of trust and commitment

European Journal of Marketing, Vol 41, No. 2 (2007): pg. 37-57. DOI. This article is @ Emerald and permission has been granted for this version to appear in e-Publications@Marquette. Emerald does not grant permission for this article to be further copied/distributed or hosted elsewhere without the express permission from Emerald. 
provide a bond among partners in the relationship that leads to extraordinary effort-what we see as the virtue of diligence.

A diligent person is defined in Webster's dictionary as being "characterized by steady, earnest and energetic application and effort." Diligence is also explained as a "persevering application" and "the attention and care legally expected or required of a person." The importance of diligence over time is reflected in the third quote heading this paper (in this instance diligence is literally caring cultivation). Hosmer (1994) uses the non-moral word "effort" to characterize this outcome and indicates that trust leads to commitment that in turn fosters a higher level of effort in stakeholder relationships. By diligence we do not, of course, refer to the legalistic requirement to show "due diligence" imposed on accountants, lawyers and others involved in mergers or acquisitions or corporate governance. Companies that exhibit diligence will foster ethical RM because if they were diligently unethical, the relationship would likely fall apart.

If trust is the bricks and commitment the mortar, diligence would be the tuck-pointing of the building. Even the sturdiest relationships will not endure without diligent maintenance. In scanning business ethics textbooks as well as the RM literature, the term diligence seldom appears. In fact, Robert Solomon (1999) lists a catalog of over forty virtues for business, yet diligence is not included. Our assessment of this finding is similar to the lack of attention to marketing "implementation" two decades ago. Diligence, like implementation, is what happens after the relationship has formed. The more attention-getting areas are those strategies leading up to implementation. We argue that just as implementation, rather than the design of a strategy, is the key to competitive success, so too diligence in relationship management is crucial to effective RM. Another way to describe this was suggested by Mahoney (1999): perseverance in the sense of steadily adhering to the ethical course of action and bringing it to completion.

Therefore, ethical RM requires not only trusting partners who are committed to making the relationship work but also a diligence to its continuation. To return to our marital analogy, maintaining the "spark" after years together necessitates diligence, i.e. the nurturing of one's already committed partner.

European Journal of Marketing, Vol 41, No. 2 (2007): pg. 37-57. DOI. This article is @ Emerald and permission has been granted for this version to appear in e-Publications@Marquette. Emerald does not grant permission for this article to be further copied/distributed or hosted elsewhere without the express permission from Emerald. 


\section{Facilitating/supporting virtues}

Relationship marketing does not occur in an ethical vacuum. It requires several other virtues to be in place to facilitate the relationship. These supporting virtues are shown in Figure 1. They are: integrity, fairness, respect and empathy.

Integrity is a hallmark virtue of all professions, including marketing. It has two meanings. The first is adherence to a moral code while the second is completeness/wholeness. Other common descriptors of integrity are coherence, honesty, moral courage and self-awareness. Integrity has been called a "supervirtue" (Solomon, 1992), "honesty with a purpose" (Murphy, 1999), having many faces (Audi and Murphy, 2006) and multiple characteristics (Gostick and Telford, 2003). Integrity usually has a lasting quality to it and in that way is a critical overlay for RM. A certain level of forthrightness is associated with firms and individuals who demonstrate the trait of integrity. Fournier et al. (1998) describe why integrity is so essential to the process:

Let's put our relationship motives on the table: no fluff, no faked sincerity, no obtuse language, no promises we don't keep-just honesty about commercial intent. We want consumers' moneylet's tell them that, and let's tell them why the deal is a good one (p. 49).

Fairness is a second critical virtue for RM. If the partners in a relationship are unfair with one another, there is little chance that it will continue. Although the definition of fairness deals with being unbiased and equitable, most individuals can recognize and articulate when they have been treated unfairly. One book described highly ethical companies as ones that are "obsessed" with fairness (Pastin, 1986). Price seems to be the marketing variable where there is the most concern about fairness. Whether a firm is a bricks and mortar one or a virtual one, consumers must have a sense that they are receiving "a fair deal." Some of the loyalty-based reward programs that are popular signal to frequent customers that they are being recognized and treated in a fair manner. While fair treatment of partners in a relationship has been recognized, ethical companies also must be aware of those who are not interested in a relationship such as the consideration due to former suppliers, clients and joint venture participants. Fairness obviously extends beyond RM partners.

European Journal of Marketing, Vol 41, No. 2 (2007): pg. 37-57. DOI. This article is @ Emerald and permission has been granted for this version to appear in e-Publications@Marquette. Emerald does not grant permission for this article to be further copied/distributed or hosted elsewhere without the express permission from Emerald. 
Respect is another virtue that often does not make the most frequently cited list (Solomon, 1999), but it appears to be increasingly important in our multicultural and (figuratively) shrinking world. Marketers, like citizens, need to find out how the other partner wishes to be respected. In international venues, this is sometimes a complicated task, yet valuing others for what they believe is critical for nurturing any relationship. Even long time relationship partners may respectfully disagree with one another on some issues. However, mutual respect between marketer and consumer is a prerequisite for a lasting interaction.

Empathy has a number of analogous meanings-the golden rule, the ethic of care and an "others" orientation. Empathetic marketers are not insensitive to the needs and concerns of the consumer. The earlier discussion of stakeholders is closely associated with empathy. For businesses that sell primarily to one another rather than to end consumers, empathy as well as trust will likely determine whether a relationship will develop over time. Empathy should not be equated with sympathy; marketers can be empathetic while still driving a hard bargain with customers.

In Figure I, transparency surrounds the entire model. This openness and clarity is an overriding virtue for RM to occur and flourish. In European circles, this term is often invoked to describe the activities of business or politicians (Eggert and Helm, 2003). Until recently, it did not have the same frequency of use in the US. Three recent books (Baum, 2004; Pagano and Pagano, 2004; Tapscott and Ticoll, 2003) and a number of discussions in the business press have advocated greater transparency by US-based companies. Of course, a transparent firm does not give away trade secrets, but at the same time does not keep its stakeholders in the dark.

\section{Implications for managers and researchers}

Several implications can be drawn for managers wishing to engage in RM that is driven by a virtue ethics approach. First, these individuals and their companies need to practice what Prahalad and Ramaswamy (2004) have called customer-centric view in which value is created through dialogue, collaboration and partnership with customers. While closeness to the customer and allowing the end consumer or B2B customer have input or "customize" products is part

European Journal of Marketing, Vol 41, No. 2 (2007): pg. 37-57. DOI. This article is @ Emerald and permission has been granted for this version to appear in e-Publications@Marquette. Emerald does not grant permission for this article to be further copied/distributed or hosted elsewhere without the express permission from Emerald. 
of this strengthened relationship, the ethical underpinnings need to be made explicit. If trust and commitment are going to solidify a relationship, recognition by both parties of the virtues inherent in genuine RM must be evident.

Second, a number of examples of the type of RM we envision are operant in both Europe and the US. Lego, the Danish building block company, has long had a co-operative empathy with the children and parents, but more recently they chose to encourage rather than sue computer enthusiasts (i.e. customers) who were tampering with the operating system of its programmable Mindstorm products. Similarly, Harley Davidson, the Milwaukee, Wisconsin motorcycle manufacturer, builds and cultivates goodwill among its fervent owners. Most of its customers are repeat buyers because of this bond that has been solidified. Ford has recently announced plans to designate fewer "strategic" suppliers and give them longer term contracts and more involvement in the design process. United Parcel Service, the Atlantabased multinational shipper, promotes informal meetings with drivers and other in-house personnel to make the job of all parties easier to accomplish. More significantly, the CEO recommends that drivers spend an extra half hour a day with end customers. This approach is a good illustration of the "diligence" stage, but also of ethical RM in general:

The dozens or hundreds of brief contacts that drivers have with particular customers build robust relationships over time. These relationships produce valuable customer information and loyalty. They sometimes develop surprising depth; one driver who had the same route for several years reports being invited to three weddings of customers' children (Cohen and Prusak, 2001, p. 97).

An implication for researchers is that the model in Figure 1 should be tested. The tie between trust and commitment has been demonstrated in the literature (Morgan and Hunt, 1994). An important research area is to better connect branding with trust and relationship building. A recent empirical study tested the concept of brand trust over several categories and concludes that consumers do in fact develop "relationships with brands" (Delgado-Ballester, 2004). This type of research could be extended to multiple facets of our model shown in Figure 1. In addition, the diligence dimension has not been proposed or tested previously to our knowledge. The anecdotal

European Journal of Marketing, Vol 41, No. 2 (2007): pg. 37-57. DOI. This article is @ Emerald and permission has been granted for this version to appear in e-Publications@Marquette. Emerald does not grant permission for this article to be further copied/distributed or hosted elsewhere without the express permission from Emerald. 
evidence of its importance is clear from many personal and business relationships. However, empirical verification through solid academic research is yet to be established. We would advocate research with several diverse firms and, especially, ones headquartered in Asia, Europe and the US.

The facilitating virtues of integrity, empathy, fairness and respect likely have differing levels of impact on RM in practice. A cross-cultural study that examines one or several of these virtues would help to clarify their relative and absolute importance in the RM process. For example, integrity is a value often espoused by companies. How is it operationalized and implemented in the firm? We could envision such research either being undertaken using a survey methodology or depth interviews. The testing of such concepts will be a difficult, but not impossible, task for empirical researchers.

Transparency as a virtue has long been recognized in Europe. The business ethics scandals of the last several years in the US have caused many more business executives in the financial and accounting world as well as writers in the US business press to include transparency in their vocabulary. Following the "ethic of the mean" such transparency obviously has its limits. The research question is whether these events have caused relationships in marketing to place greater emphasis on transparency. To date, this question about the importance of transparency in marketing has not been answered.

\section{Conclusion}

This article extends the already rich foundation of RM by advocating that this concept has a definable ethical basis. In particular, the RM stages of establishing, sustaining and reinforcing should be paired with the specific virtues of trust, commitment and diligence. Several facilitating virtues of integrity, fairness, empathy and respect are introduced and discussed in a RM context. Finally, relationships should occur with transparency of communication and action. Further conceptual and empirical work remains to be undertaken, but hopefully the ethical basis of relationship marketing is now an explicit, rather than implicit, aspect of this important development in the field of marketing.

European Journal of Marketing, Vol 41, No. 2 (2007): pg. 37-57. DOI. This article is (C) Emerald and permission has been granted for this version to appear in e-Publications@Marquette. Emerald does not grant permission for this article to be further copied/distributed or hosted elsewhere without the express permission from Emerald. 
NOT THE PUBLISHED VERSION; this is the author's final, peer-reviewed manuscript. The published version may be accessed by following the link in the citation at the bottom of the page.

\section{Notes}

1. The idea that relationship marketing progresses through a series of stages is not new. In fact, Dwyer et al. (1987) suggested a fourstep model almost 20 years ago.

2. For a comprehensive discussion of the normative underpinnings of ethical marketing, see Laczniak and Murphy (2006).

3. Homans (1974) also advocated that "balance" is an essential where mutual exchanges occur. This notion is also a central one in virtue ethics and was both introduced earlier and examined later in the paper.

\section{About the authors}

- Patrick E. Murphy is the C.R. Smith Co-Director of the Institute for Ethical Business Worldwide and Professor of Marketing in the Mendoza College of Business at the University of Notre Dame. He served as chair of the Department of Marketing for ten years. During 1993-1994 he was a Fulbright Scholar at University College Cork in Ireland. Previously, Professor Murphy was a faculty member and Marketing department chair at Marquette University. He specializes in business and marketing ethics. His work has appeared in leading journals and his most recent book (with Laczniak, N. Bowie and T. Klein) is Ethical Marketing (Prentice Hall, 2005). Patrick E. Murphy is the corresponding author and can be contacted at: Murphy.72@nd.edu

- Gene R. Laczniak is the Wayne and Kathleen Sanders Professor of Marketing in the Straz College of Business Administration at Marquette University. He is a former chair of the Marketing Department there with ten years of service. From 1998 to 2002, Laczniak was the Associate Vice President/Provost for Academic Affairs at the university. He has been a Visiting Professor or Visiting Fellow at the University of Western Australia (Perth) on several occasions. Laczniak's research focuses on the influence of marketing strategy on society especially on questions of ethics.

- Graham Wood is Senior Lecturer in Strategy and Ethics at the newly formed Salford Business School, University of Salford, UK. His research interests revolve around issues of trust and trust-building processes in inter-organizational relationships, ethics in marketing and social capital. He has published a number of papers in these areas in various journals. Currently he is focused on his role as Director of Postgraduate Programs in the new Salford Business School.

European Journal of Marketing, Vol 41, No. 2 (2007): pg. 37-57. DOI. This article is (C) Emerald and permission has been granted for this version to appear in e-Publications@Marquette. Emerald does not grant permission for this article to be further copied/distributed or hosted elsewhere without the express permission from Emerald. 
NOT THE PUBLISHED VERSION; this is the author's final, peer-reviewed manuscript. The published version may be accessed by following the link in the citation at the bottom of the page.

\section{References}

Alderson, W. (1957), Marketing Behavior and Executive Action: A Functionalist Approach to Marketing Theory, Irwin, Homewood, IL.

Anderson, J.C. and Narus, J.A. (1990), "A model of distributor firm and manufacturer firm working partnerships", Journal of Marketing, Vol. 54 No. 1, pp. 42-58.

Anderson, J.C. and Weitz, B. (1989), "Determinants of continuity in conventional industrial channel dyads", Marketing Science, Vol. 8 No. 4, pp. 310-23.

Anton, J. (1996), Customer Relationship Management: Making Hard Decisions with Soft Numbers, Prentice Hall, Upper Saddle River, NJ.

Arias, G. and Tomas, J. (1998), "A relationship marketing approach to guanxi", European Journal of Marketing, Vol. 32 Nos 1/2, pp. 145-56.

Audi, R. and Murphy, P. (2006), "The many faces of integrity", Business Ethics Quarterly, Vol. 16 No. 1, pp. 3-22.

Baker, M. (1994), "Editorial", Journal of Marketing Management, Vol. 10 No. 2, pp. 343-6.

Ballantyne, D. (2003), "A relationship-mediated theory of internal marketing", European Journal of Marketing, Vol. 37 No. 9, pp. 1242-60.

Barnes, J.G. (2001), Secrets of Customer Relationship Management: It's All About How You Make Them Feel, McGraw-Hill, New York, NY.

Batonda, G. and Perry, C. (2003a), "Approaches to relationship development processes in inter-firm networks", European Journal of Marketing, Vol. 37 No. 10, pp. 1457-84.

Batonda, G. and Perry, C. (2003b), "Influence of culture on relationship development processes in overseas Chinese/Australian networks", European Journal of Marketing, Vol. 37 Nos 11/12, pp. 1548-74.

Baum, H. (2004), The Transparent Leader, HarperCollins, New York, NY.

Berry, L.L. (1995), "Relationship marketing of services-growing interest, emerging perspectives", Journal of the Academy of Marketing Science, Vol. 23 No. 4, pp. 236-45.

Bitner, M.J. (1995), "Building service relationships: it's all about promises", Journal of the Academy of Marketing Science, Vol. 23 No. 4, pp. 24651.

Buttle, F. (1996), "Relationship marketing", Relationship Marketing Theory and Practice, Paul Chapman Publishing, London.

Buttle, F. (2004), Customer Relationship Management: Concepts and Tools, Elsevier Butterworth-Heinemann, Oxford.

Chaston, I. and Mangles, T. (2003), "Relationship marketing in online business-to-business markets: a pilot investigation of small UK manufacturing firms", Journal of European Marketing, Vol. 37 Nos 5/6, pp. 753-73.

European Journal of Marketing, Vol 41, No. 2 (2007): pg. 37-57. DOI. This article is (C) Emerald and permission has been granted for this version to appear in e-Publications@Marquette. Emerald does not grant permission for this article to be further copied/distributed or hosted elsewhere without the express permission from Emerald. 
NOT THE PUBLISHED VERSION; this is the author's final, peer-reviewed manuscript. The published version may be accessed by following the link in the citation at the bottom of the page.

Christopher, M., Payne, A. and Ballantyne, D. (1991), Relationship Marketing: Bringing Quality, Customer Service, and Marketing Together, Butterworth-Heinemann, Oxford.

Cohen, D. and Prusak, L. (2001), In Good Company: How Social Capital Makes Organizations Work, Harvard Business School Press, Boston, MA.

Crosby, L.A., Evans, K.R. and Cowles, D. (1990), "Relationship quality in services selling: an interpersonal influence perspective", Journal of Marketing, Vol. 54 No. 3, pp. 68-81.

Davis, F.W. and Mandrodt, K.B. (1996), Customer-Responsive Management: The Flexible Advantage, Blackwell Publishers, Cambridge, MA.

Day, G.S. (1995), "Advantageous alliances", Journal of the Academy of Management Science, Vol. 23 No. 4, pp. 297-300.

Delgado-Ballester, E. (2004), "Applicability of a brand trust scale across product categories: a multigroup invariance analysis", European Journal of Marketing, Vol. 38 Nos 5/6, pp. 573-92.

Doherty, A.M. and Alexander, N. (2004), "Relationship development in international retail franchising", European Journal of Marketing, Vol. 38 Nos 9/10, pp. 1215-35.

Drucker, P.F. (1973), Management: Tasks, Responsibilities, Practices, Harper \& Row, New York, NY.

Drucker, P.F. (1979), Adventures of a Bystander, Harper \& Row, New York, NY.

Dwyer, F.R., Schurr, P.H. and Oh, S. (1987), "Developing buyer-seller relationships", Journal of Marketing, Vol. 51 No. 3, pp. 11-27.

Eggert, A. and Helm, S. (2003), "Exploring the impact of relationship transparency on business relationships: a cross-sectional study among purchasing managers in Germany", Industrial Marketing Management, Vol. 32, pp. 101-8.

Farrellly, F. and Quester, P. (2003), "The effect of market orientation on trust and commitment: the case of the sponsorship business-to-business relationship", European Journal of Marketing, Vol. 37 Nos 3/4, pp. 530-53.

Fisk, G. (1967), Marketing Systems: An Introductory Analysis, Harper \& Row, New York, NY.

Ford, D. (1990), Understanding Business Markets, Academic Press, London.

Fournier, S., Dobscha, S. and Mick, D.G. (1998), "Preventing the premature death of relationship marketing", Harvard Business Review, Vol. 76 Nos 1/2, pp. 42-53.

Fukuyama, F. (1995), Trust: The Social Virtues and the Creation of Prosperity, The Free Press, New York, NY.

European Journal of Marketing, Vol 41, No. 2 (2007): pg. 37-57. DOI. This article is (C) Emerald and permission has been granted for this version to appear in e-Publications@Marquette. Emerald does not grant permission for this article to be further copied/distributed or hosted elsewhere without the express permission from Emerald. 
NOT THE PUBLISHED VERSION; this is the author's final, peer-reviewed manuscript. The published version may be

accessed by following the link in the citation at the bottom of the page.

Fullerton, G. (2005), "How commitment both enables and undermines marketing relationships", European Journal of Marketing, Vol. 39 Nos $11 / 12$, pp. $1372-88$.

Gambetta, D. (1988), Trust: Making and Breaking Cooperative Relations, Basil Blackwell, New York, NY.

Ganesan, S. (1994), "Determinants of long-term orientation in buyer-seller relationships", Journal of Marketing, Vol. 58 No. 4, pp. 1-19.

Garbarino, E. and Johnson, M.S. (1999), "The different roles of satisfaction, trust, and commitment in customer relationships", Journal of Marketing, Vol. 63 No. 2, pp. 70-87.

Gemünden, H.G., Ritter, T. and Walter, A. (1997), Relationships and Networks in International Markets, Redwood Books, Trowbridge.

Gherardi, S. and Masiero, A. (1990), "Solidarity as a networking skill and a trust relation: its implications for cooperative development", Economic and Industrial Democracy, Vol. 11, pp. 553-74.

Good, D. and Evans, K. (2001), "Relationship unrest: strategic perspectives for business-to-business marketers", European Journal of Marketing, Vol. 35 Nos 5/6, pp. 549-65.

Gordon, I. (1998), Relationship Marketing: New Strategies, Techniques and Technologies to Win the Customers You Want and Keep Them Forever, John Wiley, New York, NY.

Gostick, A. and Telford, D. (2003), The Integrity Advantage, Gibbs Smith, Salt Lake City, UT.

Gruen, T.W., Summers, J.O. and Acito, F. (2000), "Relationship marketing activities, commitment, and membership behavior activities", Journal of Marketing, Vol. 64 No. 3, pp. 1-17.

Grönroos, C. (1989), "Defining marketing: a market-oriented approach", European Journal of Marketing, Vol. 23 No. 1, pp. 52-60.

Grönroos, C. (1991), "The marketing strategy continuum: towards a marketing concept for the 1990s", Management Decision, Vol. 29 No. 1, pp. 7-13.

Grönroos, C. (1994), "Quo vadis, marketing? Towards a relationship paradigm", Journal of Marketing Management, Vol. 10 No. 2, pp. 34760.

Gummesson, E. (1987), "The new marketing-developing long-term interactive relationships", Long Range Planning, Vol. 20 No. 4, pp. 10-20.

Gummesson, E. (1999), Total Relationship Marketing, ButterworthHeinemann, Boston, MA.

Gundlach, G.T. and Murphy, P.E. (1993), "Ethical and legal foundations of relational marketing exchanges", Journal of Marketing, Vol. 57 No. 4, pp. 35-46.

European Journal of Marketing, Vol 41, No. 2 (2007): pg. 37-57. DOI. This article is (C) Emerald and permission has been granted for this version to appear in e-Publications@Marquette. Emerald does not grant permission for this article to be further copied/distributed or hosted elsewhere without the express permission from Emerald. 
NOT THE PUBLISHED VERSION; this is the author's final, peer-reviewed manuscript. The published version may be

accessed by following the link in the citation at the bottom of the page.

Gundlach, G.T., Achrol, R.A. and Mentzer, J.T. (1995), "The structure of commitment in exchange", Journal of Marketing, Vol. 59 No. 1, pp. 7892.

Gwinner, K.P., Gremler, D.D. and Bitner, M.J. (1998), "Relational benefits in service industries: the customer's perspective", Journal of the Academy of Marketing Science, Vol. 26 No. 2, pp. 101-14.

Hakansson, H. (Ed.) (1982), International Marketing and Purchasing of Industrial Goods, Wiley, Chichester.

Hawes, J.M. (1994), "To know me is to trust me", Industrial Marketing Management, Vol. 23, pp. 215-9.

Hawes, J.M., Mast, K.E. and Swan, J.E. (1989), "Trust earning perceptions of sellers and buyers", Journal of Personal Selling and Sales Management, Vol. 9, pp. 1-8.

Healy, M., Hastings, K., Brown, L. and Gardiner, M. (2001), "The old, the new and the complicated: a trilogy of marketing relationships", European Journal of Marketing, Vol. 35 Nos 1/2, pp. 182-93.

Homans, G.C. (1974), Social Behavior: Its Elementary Forms, Harcourt Brace Jovanovich, New York, NY.

Hosmer, L.T. (1994), "Why be moral? A different rationale for managers", Business Ethics Quarterly, Vol. 4, pp. 191-204.

Hosmer, L.T. (1995), "Trust: the connection link between organizational theory and philosophical ethics", Academy of Management Review, Vol. 20 No. 2, pp. 379-403.

Hougaard, S., Bjarre, M. and Hougaard, S. (2004), Strategic Relationship Marketing, Springer, Berlin.

Izquierdo, C.C. and Cillan, J.G. (2004), "The interaction of dependence and trust in long-term industrial relationships", European Journal of Marketing, Vol. 38 No. 8, pp. 974-94.

Joshi, A.W. (1994), "Ethical and unethical behavior in exchange relationships: a contingency theory", in Sheth, J. and Parvatiyar, A. (Eds), Relationship Marketing: Theory, Methods and Applications, Emory University Center of Relationship Marketing, Atlanta, GA, pp. 1-2.

Juttner, U. and Wehrli, H.P. (1994), "Relationship marketing from a value system perspective", International Journal of Service Industry Management, Vol. 5 No. 5, pp. 54-73.

Kavaili, S.G., Tzokas, N.X. and Saren, M.J. (1999), "Relationship marketing as an ethical approach: philosophical and managerial considerations", Management and Decisions, Vol. 37 No. 7, pp. 573-81.

Keep, W.W., Hollander, S.C. and Dickinson, R. (1996), "Relationship commitment, trust and non-opportunistic behavior: comparing selected business and social values", in Droge, C. et al. (Eds), AMA Educators' Conference Proceedings, American Marketing Association, Chicago, IL, pp. 289-97.

European Journal of Marketing, Vol 41, No. 2 (2007): pg. 37-57. DOI. This article is (C) Emerald and permission has been granted for this version to appear in e-Publications@Marquette. Emerald does not grant permission for this article to be further copied/distributed or hosted elsewhere without the express permission from Emerald. 
NOT THE PUBLISHED VERSION; this is the author's final, peer-reviewed manuscript. The published version may be

accessed by following the link in the citation at the bottom of the page.

Kotler, P. and Keller, K.L. (2006), Marketing Management, 12th ed., Pearson Prentice-Hall, Upper Saddle River, NJ.

Laczniak, G.R. and Murphy, P.E. (2006), "Normative perspectives for ethical and socially responsible marketing", Journal of Macromarketing, Vol. 26, pp. 154-77.

Lee, D.J., Pae, J.H. and Wong, Y.H. (2001), "A model of close business relationships in China (guanxi)", European Journal of Marketing, Vol. 35 Nos 1/2, pp. 51-69.

Leung, T.K.P., Lai, K.H., Chan, R.Y.K. and Wong, Y.H. (2005), "The roles of xinyong and guanxi in Chinese relationship marketing", European Journal of Marketing, Vol. 39 Nos 5/6, pp. 528-59.

McKenna, R. (1991), Relationship Marketing, Addison-Welsey, Reading, MA.

MacIntyre, A. (1984), After Virtue, University of Notre Dame Press, Notre Dame, IN.

Mahoney, J. (1999), "Cultivating moral courage in business", in Enderle, G. (Ed.), International Business Ethics: Challenges and Approaches, University of Notre Dame Press, Notre Dame, IN, pp. 249-59.

Mattson, L.G. (1997), "'Relationship marketing' and the 'markets as networks approach': a comparative analysis of two evolving streams of research", Journal of Marketing Management, Vol. 13 No. 5, pp. 44761.

Mittal, B. (1996), "Trust and relationship quality: a conceptual excursion", in Parvatiyar, A., Sheth, J.N., Contemporary Knowledge of Relationship Marketing, Research Conference Proceedings, Center for Relationship Marketing, Emory University, Atlanta, GA.

Moorman, C., Zaltman, G. and Deshpande, R. (1992), "Relationships between providers and users of market research: the dynamics of trust within and between organizations", Journal of Marketing Research, Vol. 29, August, pp. 314-28.

Moorman, C., Deshpande, R. and Zaltman, G. (1993), "Factors affecting trust in market research relationships", Journal of Marketing, Vol. 57, pp. 81-101.

Morgan, R.M. and Hunt, S.D. (1994), "The commitment-trust theory of relationship marketing", Journal of Marketing, Vol. 58, July, pp. 20-38.

Murphy, P.E. (1999), "Character and virtue ethics in international marketing: an agenda for managers, researchers and educators", Journal of Business Ethics, Vol. 18, pp. 107-24.

Murphy, P.E., Laczniak, G.R., Bowie, N.E. and Klein, T.A. (2005), Ethical Marketing, Pearson Prentice Hall, Upper Saddle River, NJ.

Nantel, J. and Weeks, W.A. (1996), "Marketing ethics: is there more to it than the utilitarian approach?", European Journal of Marketing, Vol. 30 No. 5, pp. 9-19.

European Journal of Marketing, Vol 41, No. 2 (2007): pg. 37-57. DOI. This article is (C) Emerald and permission has been granted for this version to appear in e-Publications@Marquette. Emerald does not grant permission for this article to be further copied/distributed or hosted elsewhere without the express permission from Emerald. 
NOT THE PUBLISHED VERSION; this is the author's final, peer-reviewed manuscript. The published version may be accessed by following the link in the citation at the bottom of the page.

Nooteboom, B. (1992), "Marketing, reciprocity and ethics", Business Ethics: A European Review, Vol. 1 No. 2, pp. 110-6.

Norberg, P.A. (2001), "Relationship issues in business-to-consumer markets", Proceedings of AMA Summer Conference, pp. 381-7.

O’Malley, L. and Tynan, C. (2000), "Relationship marketing in consumer markets: rhetoric or reality?", European Journal of Marketing, Vol. 34 No. 7, pp. 797-815.

Oliver, R.L. (1999), "Whence consumer loyalty?", Journal of Marketing, Vol. 63, pp. 33-44.

Pagano, B. and Pagano, E. (2004), The Transparency Edge: How Credibility Can Make or Break You in Business, McGraw-Hill, New York, NY.

Palmer, A. (2000), "Co-operation and competition: a Darwinian synthesis of relationship marketing", European Journal of Marketing, Vol. 34 Nos 5/6, pp. 687-704.

Parvatiyar, A. and Sheth, J.N. (Eds) (1996), "Contemporary knowledge of relationship marketing", Research Conference Proceedings, Center for Relationship Marketing, Emory University, Atlanta, GA.

Pastin, M. (1986), The Hand Problems of Management: Gaining the Ethics Edge, Jossey-Bass, San Francisco, CA.

Payne, A., Ballantyne, D. and Christopher, M. (2005), "A stakeholder approach to relationship marketing strategy: the development and use of the 'six markets' model", European Journal of Marketing, Vol. 39 Nos 7/8, pp. 855-71.

Pollard, C.W. (1996), The Soul of the Firm, Harper Business and Zondervan Publishing House, Grand Rapids, MI.

Prahalad, C.K. and Ramaswamy, V. (2004), The Future of Competition: CoCreating Unique Value with Customers, Harvard Business School Publishing, Boston, MA.

Ravald, A. and Gronroos, C. (1996), "The value concept and relationship marketing", European Journal of Marketing, Vol. 30 No. 2, pp. 19-30.

Roberts, K., Varki, S. and Brodie, R. (2003), "Measuring the quality of relationships in consumer services: an empirical study", European Journal of Marketing, Vol. 37 Nos 1/2, pp. 169-96.

Rokkan, A.I. and Haugland, S.A. (2002), "Developing relational exchange: effectiveness and power", European Journal of Marketing, Vol. 36 Nos 1/2, pp. 211-30.

Rotter, J.B. (1967), "A new scale for the management of trust", Journal of Personality, Vol. 35, pp. 651-65.

Salmond, D. (1994), "Refining the concept of trust in business-to-business relationship theory, research and management", in Sheth, J. and Parvatiyar, A. (Eds), Relationship Marketing: Theory, Methods and Applications, Emory University Center of Relationship Marketing, Atlanta, GA, pp. 1-12.

European Journal of Marketing, Vol 41, No. 2 (2007): pg. 37-57. DOI. This article is (C) Emerald and permission has been granted for this version to appear in e-Publications@Marquette. Emerald does not grant permission for this article to be further copied/distributed or hosted elsewhere without the express permission from Emerald. 
NOT THE PUBLISHED VERSION; this is the author's final, peer-reviewed manuscript. The published version may be accessed by following the link in the citation at the bottom of the page.

Selnes, F. (1998), "Antecedents and consequences of trust and satisfaction in buyer-seller relationships", European Journal of Marketing, Vol. 32 Nos 3/4, pp. 305-22.

Shaw, R.B. (1997), Trust in the Balance: Building Successful Organizations on Results, Integrity, and Concern, Jossey-Bass Publishers, San Francisco, CA.

Sheth, J.N. and Parvatiyar, A. (Eds) (1994), "Relationship marketing: theory, methods and applications", Research Conference Proceedings, Center for Relationship Marketing, Emory University, Atlanta, GA.

Sirdeshmukh, D., Singh, J. and Sabol, B. (2002), "Consumer trust, value, and loyalty in relational exchanges", Journal of Marketing, Vol. 66, pp. 1537.

Soellner, A.O.E. (1994), "Commitment in exchange relationships: the role of switching costs in building and sustaining competitive advantages", in Sheth, J.N. and Parvatiyar, A. (Eds), Relationship Marketing: Theory, Methods and Applications, Emory University, Atlanta, GA, pp. 1-12.

Soellner, A.O.E. (1996), "The role of morality as an institution in relationship marketing", in Parvatiyar, A. and Sheth, J.N. (Eds), Contemporary Knowledge of Relationship Marketing, Emory University, Atlanta, GA, pp. $42-4$

Solomon, R.C. (1992), Ethics and Excellence: Cooperation and Integrity in Business, Oxford University Press, New York, NY.

Solomon, R.C. (1999), A Better Way to Think About Business: How Personal Integrity Leads to Corporate Success, Oxford University Press, New York, NY.

Solomon, R.C. and Flores, F. (2001), Building Trust in Business, Politics, Relationships, and Life, Oxford University Press, New York, NY.

Sultan, F. and Mooraj, H.A. (2001), "Designing a trust-base e-business strategy", Marketing Management, pp. 40-5.

Swan, J.E., Fredrick, T.I. and Silva, D.W. (1985), "How industrial salespeople gain customer trust", Industrial Marketing Management, Vol. 14, pp. 203-11.

Tapscott, D. and Ticoll, D. (2003), The Naked Corporation: How the Age of Transparency Will Revolutionize Business, Free Press, New York, NY.

Urban, G.L. (2005a), "Customer advocacy: a new era in marketing?", Journal of Public Policy and Marketing, Vol. 24, Spring, pp. 155-9.

Urban, G.L. (2005b), Don't Just Relate - Advocate! A Blueprint for Profit in the Era of Customer Power, Wharton School Publishing, Upper Saddle River, NJ.

Varva, T.G. (1992), Aftermarketing: How to Keep Customers for Life Through Relationship Marketing, Business One Irwin, Homewood, IL.

Veloutsou, C., Saren, M. and Hutcheson, G. (2002), "Relationship marketing: what if...?", European Journal of Marketing, Vol. 36 No. 4, pp. 433-49.

European Journal of Marketing, Vol 41, No. 2 (2007): pg. 37-57. DOI. This article is (C) Emerald and permission has been granted for this version to appear in e-Publications@Marquette. Emerald does not grant permission for this article to be further copied/distributed or hosted elsewhere without the express permission from Emerald. 
Venetis, K.A. and Ghauri, P.N. (2004), "Service quality and customer retention: building long-term relationships", European Journal of Marketing, Vol. 38 Nos 11/12, pp. 1577-98.

White, S.S. and Schneider, B. (2000), "Climbing the commitment ladder: the role of expectations disconfirmation on customers' behavioral intentions", Journal of Service Research, Vol. 2, pp. 40-253.

Williams, O.F. and Murphy, P.E. (1992), "The ethics of virtue: a moral theory for business", in Williams, O. and Houck, J. (Eds), A Virtuous Life in Business, Roman \& Littlefield, Lanham, MD, pp. 9-27.

Wilson, D.T. (1995), "An integrated model of buyer-seller relationships", Journal of the Academy of Marketing Science, Vol. 23 No. 4, pp. 33545.

Wood, G., McDermott, P. and Swan, W. (2002), "The ethical benefits of trustbased partnering: the example of the construction industry", Business Ethics: A European Review, Vol. 11 No. 1, pp. 4-13.

Yau, O.H.M., McFetridge, P.R., Chow, R.P.M., Lee, J.S.Y., Sin, L.Y.M. and Tse, A.C.B. (2000), "Is relationship marketing for everyone?", European Journal of Marketing, Vol. 34 Nos 9/10, pp. 1111-27.

Young, L.C. and Wilkinson, I.F. (1989), "The role of trust and co-operation in marketing channels: a preliminary study", European Journal of Marketing, Vol. 23 No. 2, pp. 109-22.

Zineldin, M.A. (1998). "Towards an ecological collaborative relationship management a 'co-opetive' perspective", European Journal of Marketing, Vol. 32 No. 11/12, pp. 1138-64.

European Journal of Marketing, Vol 41, No. 2 (2007): pg. 37-57. DOI. This article is @ Emerald and permission has been granted for this version to appear in e-Publications@Marquette. Emerald does not grant permission for this article to be further copied/distributed or hosted elsewhere without the express permission from Emerald. 
NOT THE PUBLISHED VERSION; this is the author's final, peer-reviewed manuscript. The published version may be accessed by following the link in the citation at the bottom of the page.

\section{Appendix}

Table I Recent relationship marketing articles in European Journal of Marketing

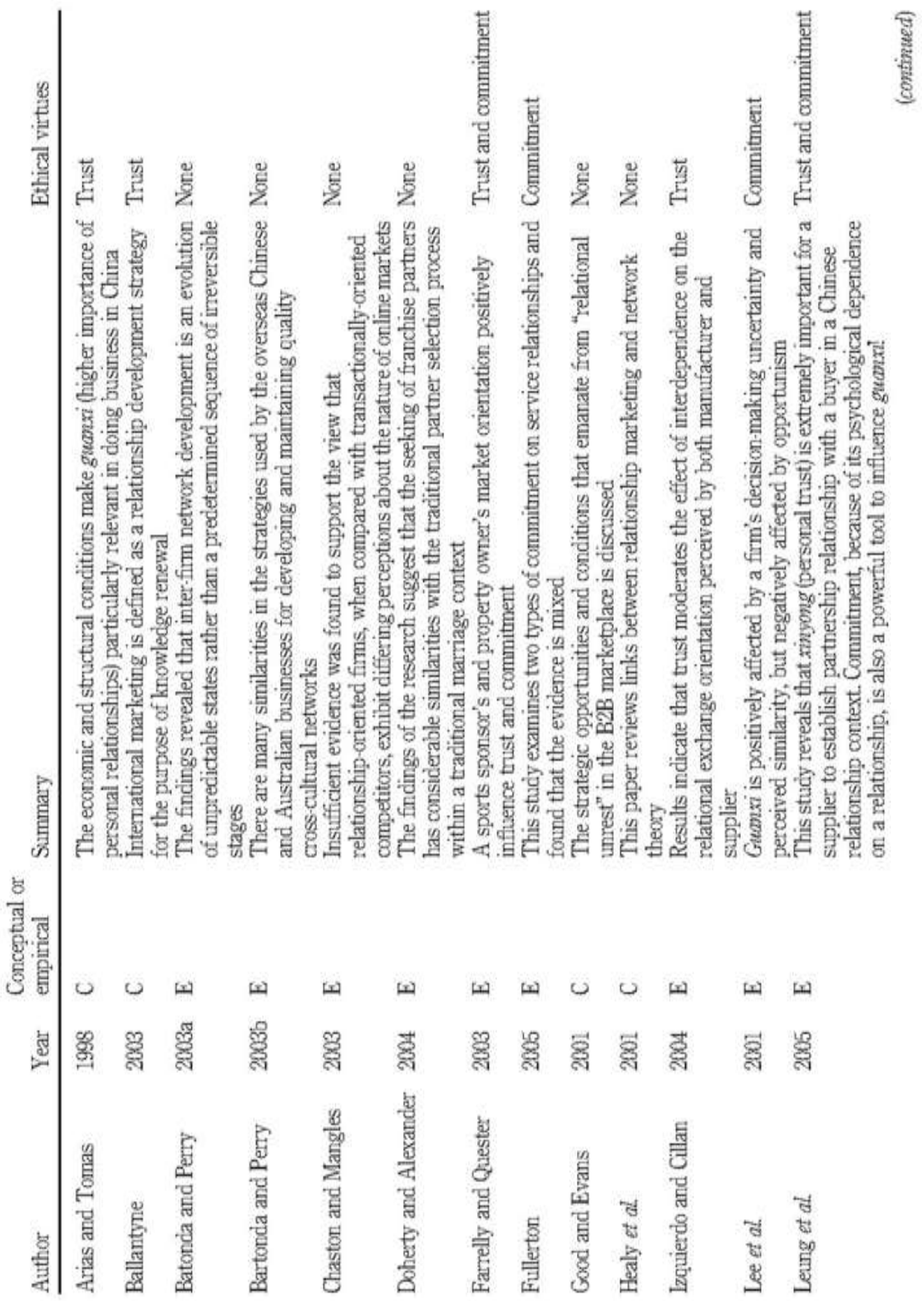

European Journal of Marketing, Vol 41, No. 2 (2007): pg. 37-57. DOI. This article is @ Emerald and permission has been granted for this version to appear in e-Publications@Marquette. Emerald does not grant permission for this article to be further copied/distributed or hosted elsewhere without the express permission from Emerald. 
NOT THE PUBLISHED VERSION; this is the author's final, peer-reviewed manuscript. The published version may be accessed by following the link in the citation at the bottom of the page.

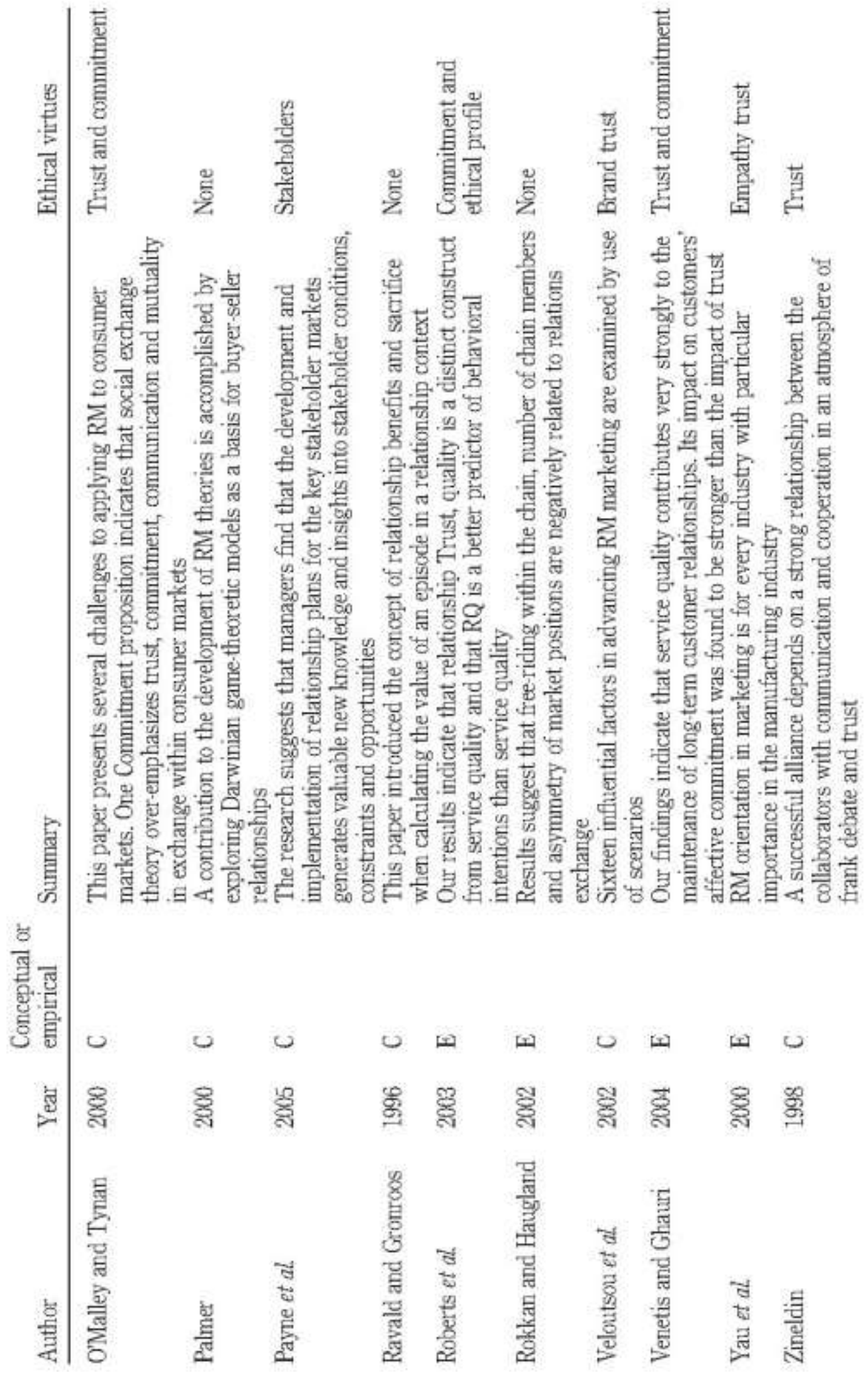

European Journal of Marketing, Vol 41, No. 2 (2007): pg. 37-57. DOI. This article is @ Emerald and permission has been granted for this version to appear in e-Publications@Marquette. Emerald does not grant permission for this article to be further copied/distributed or hosted elsewhere without the express permission from Emerald. 
NOT THE PUBLISHED VERSION; this is the author's final, peer-reviewed manuscript. The published version may be accessed by following the link in the citation at the bottom of the page.

Figure 1 Ethical bases of relationship marketing

\section{Transparency ${ }^{d}$}

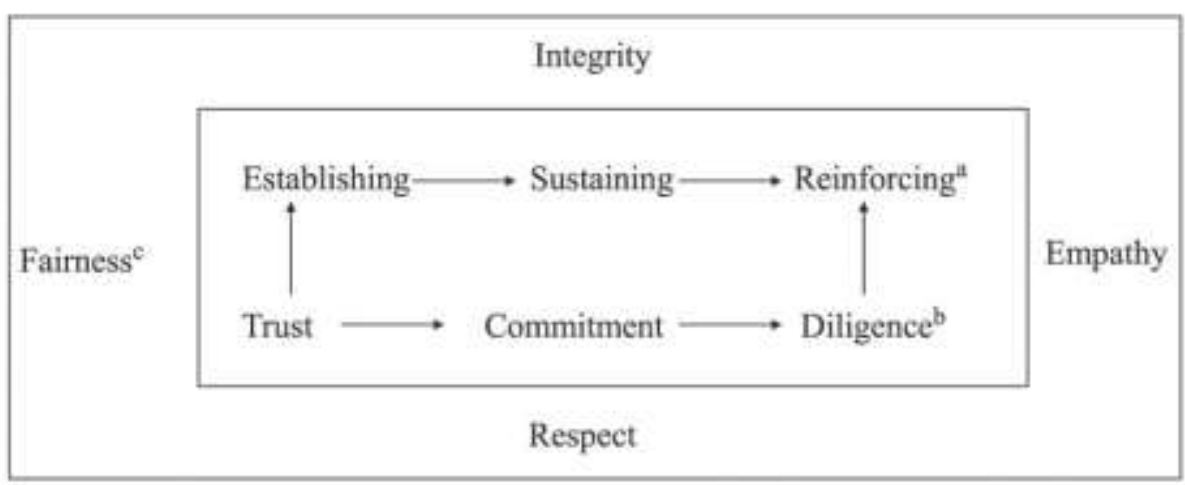

Key:

"Relationship Marketing Stages

${ }^{\mathrm{b}} \mathrm{Key}$ (Foundational) Virtues

${ }^{\mathrm{C}}$ Facilitating (Supporting) Virtues

${ }^{\mathrm{I} I n}$ Communication and Action 